\title{
Determination of Nucleotide Sequences of Mitochondrial Plasmid pGT704 of Paramecium caudatum
}

\author{
TE. Tallei ${ }^{1}$, MR. Moeis ${ }^{2}$, H. Endoh ${ }^{3}$ dan W. Utama ${ }^{4}$
}

\begin{abstract}
Many kinds of linear plasmids, or plasmid-like DNAs, in mitochondria have been reported in higher plants and fungi. Nevertheless, such plasmids were not previously known from the animal kingdom. Paramecium is the first example in which a mitochondrial plasmid-like DNA so far discovered among ciliates. In natural stocks, $P$. caudatum has one of three types of DNA : type I $(6.4 \mathrm{~kb})$, type II, a set of four DNAs $(8.2 \mathrm{~kb} ; 4.1 \mathrm{~kb} ; 2.8 \mathrm{~kb}$; and $1.4 \mathrm{~kb})$ and type III (8.6 kb). Paramecium caudatum stock GT704 only has type-II DNA. The 8.2 and $2.8 \mathrm{~kb}$ DNAs are dimers of the 4.1 and $1.4 \mathrm{~kb}$ DNA, respectively. The aim of this study was to determine the sequence of mitochondrial plasmid-like DNA in $P$. caudatum stock GT704 in order to identify potential gene products and other nucleotide sequences that might have relationship with integration of DNA and also the maintanance of DNA itself in mitochondria. The methods used in this study were isolation of the DNA, cloning and sequencing then followed by analysis of sequences obtained using available public domain. The dimers were found to be easily dissociated to monomers when treated with heat underconditions of low ionic strength. These results suggest that each monomer has a sticky end of single-stranded DNA that has complementary nucleotide sequences, and so attaches to each other at the end by base-pairing to form a dimer, leaving a nick that can be filled by ligation using ligase. Nucleotide sequences of some part of the DNA have been obtained randomly. Sequence analysis suggests that these dimers DNAs have 2 ORFs that code for putative RNA and DNA polymerases. It is assumed that the origin of this mitochondrial plasmid-like DNA is transposable element or some viruses since the motif EVI-1 (ectopic viral integration site-1) was found in the sequence. It is also assumed that this DNA can integrate into mtDNA since it also has some sequences homolog to the sequences of $\mathrm{mt}$ DNA of some ciliates.
\end{abstract}

Keywords-Paramecium caudatum, Linear plasmid, Mitochondria, Putative RNA and DNA polymerases.

\section{PENDAhUluan}

$\mathrm{B}$ erbagai plasmid dalam mitokondria telah ditemukan pada tanaman tingkat tinggi dan jamur. Penemuan plasmid mitokondria pada protozoa bersilia Paramecium merupakan contoh pertama dalam eukariota selain yang telah disebutkan di atas, yang sekaligus menjadikan contoh pertama plasmid mitokondria pada king-

Naskah diterima 5 Januari 2006, Selesai revisi pada 5 Mei 2008

${ }^{1}$ TE. Tallei adalah dosen Jurusan Biologi, FMIPA, Universitas Sam Ratulangi, Manado, INDONESIA. (email: trinatallei@ yahoo.com)

2 MR. Moeis adalah dosen Jurusan Biologi, FMIPA, Institut Teknologi Bandung, Bandung, INDONESIA

H. Endoh adalah dosen Jurusan Biologi, Fakultas Sains Universitas Kanazawa, JEPANG

${ }^{4}$ W. Utama adalah dosen Prodi Geofisika, Jurusan Fisika, FMIPA, Institut Teknologi Sepuluh Nopember, Surabaya, INDONESIA dom hewan [1]. Kehadiran beberapa plasmid, seperti plasmid kalilo dan maranhar dalam Neurospora, berhubungan dengan senesen. Proses degeneratif ini dihasilkan dari bermacam-macam mutasi dalam genom mitokondria (mtDNA) dan dicirikan dengan pertumbuhan lambat, kehilangan fertilitas organisme betina, dan mitokondria cacat seperti defisiensi sitokrom aa3 dan b. Senesen juga dapat diinduksi melalui integrasi plasmidplasmid linier tersebut ke dalam genom mitokondria. Pada gilirannya akumulasi superesif dari mtDNA defektif yang mengambil alih fungsi mitokondria normal dapat menyebabkan kematian organisme[2].

Plasmid-plasmid yang telah diteliti dengan sangat mendalam adalah plasmid linier kalilo dan maranhar. Plasmid-plasmid tersebut memiliki karakteristik sebagai berikut : Pertama, memiliki "terminal inverted repead" (TIR). Kedua, pada masing-masing ujung DNA terdapat protein yang berikatan dengan ujung 5'. Ketiga, dimulai dari tengah-tengah "terminal repeat", ada dua "open reading frame" (ORF) besar yang tidak tumpang tindih satu sama lain. "Reading frame" ini hanya bisa terbuka apabila digunakan kode genetik khusus untuk mitokondria [3]. Menurut beberapa data hasil pengurutan nukleotida, selain mengkode DNA dan RNA polimerase, ORF juga diperlukan untuk replikasi plasmid-plasmid itu sendiri [4], [5].

Menurut referensi [1], plasmid yang ditemukan pada mitokondria Paramecium dapat dibagi atas dua kelompok: tipe I yang dideteksi sebagai suatu pita tunggal dan tipe II yang dideteksi sebagai satu kumpulan dari empat pita dalam gel elektroforesis. Tipe I tidak hanya terdapat pada Paramecium caudatum, akan tetapi juga pada spesies Paramecium lainnya. Plasmid pada $P$. caudatum memiliki suatu protein terminal pada salah satu ujung dan "hairpin" pada ujung lainnya, sama dengan ciri plasmid-plasmid linier lainnya. Tipe II sangat jarang ditemukan pada stok alamiah dari $P$. caudatum. Masih sangat sedikit ditemukan informasi tentang struktur DNA tipe II ini [1], [6].

Struktur molekuler DNA plasmid tipe II yang diisolasi dari mitokondria $P$. Caudatum selalu dapat dideteksi sebagai suatu kumpulan dari empat macam ukuran yaitu 8,$2 ; 4,1 ; 2,8$ dan $1,4 \mathrm{~kb}$. DNA $8,2 \mathrm{~kb}$ dan $2,8 \mathrm{~kb}$ berada dalam bentuk dimer yang terdiri dari molekul-molekul monomer masing-masing 4,1 kb dan 1,4 kb. Pemeriksaan mikroskop elektron menandakan adanya konfigurasi struktur "hairpin" yang memiliki ujung lengket ("sticky end") dan "loop" pada ujung lainnya. Monomer-monomer bersatu dengan cara berpasangan dalam arah yang berlawanan pada ujung lengket untuk membentuk dimer. 
Dimer yang tidak biasa ini mungkin memiliki tugas dalam replikasi dari DNA, dengan cara monomer yang satu bertindak sebagai primer bagi monomer lainnya [1].

Tujuan penelitian ini adalah menentukan urutan nukleotida plasmid yang yang diisolasi dan diklon dari mitokondria Paramecium caudatum stok GT704 untuk mengidentifikasi produk-produk gen yang terlibat dalam proses pemeliharaan diri plasmid tersebut dan menentukan urutan nukleotida yang terlibat dalam proses integrasi atau delesi.

\section{MATERI DAN METODE}

\section{A. Isolasi mitokondria dan DNA plasmid}

Prosedur isolasi mitokondria dilakukan berdasarkan metode standar [7] dengan sedikit modifikasi. Pelet mitokondria dilisis dalam TE $\mathrm{pH} 8$ dan proteinase $\mathrm{K}$ selama 3 jam suhu $50^{\circ} \mathrm{C}$. DNA diperoleh dengan ekstraksi fenol. Pemeriksaan dilanjutkan untuk memastikan kandungan DNA plasmid seperti yang diharapkan. DNA dimer diligasi menggunakan ligase kemudian diisolasi dari gel dengan menggunakan DNA Purification System (BioRad). DNA dimer di potong dengan HindIII dan disisipkan pada vektor pBluescript SK (+/-) kemudian dilakukan proses transformasi menggunakan metode standar (Novagen) dengan menggunakan sel kompeten XL1BLue. Vektor yang berisi sisipan lantas dianalisis untuk memperoleh urutan nukleotida sisipannya.

\section{B. Analisis Urutan Nukleotida}

Dalam penelitian ini nukleotida yang disekuens adalah hasil random cloning dan bukan seluruh sekuens dari plasmid pGT704-2,8 dan pGT704-8,2.

DNA yang digunakan untuk pengurutan nukleotida adalah DNA yang dimurnikan dengan "Wizard Plus SV Minipreps DNA Purification System" (Promega). Alat penentu urutan nukleotida DNA yang digunakan adalah ALOKA DNA sequencing system Model LIC-420 OL (S)-1. Reaksi penentuan urutan nukleotida DNA adalah sebagai berikut: DNA templat; "IRD800 labeled-primer" (M13 forward atau M13 reverse); $10 \mathrm{X}$ "sequencing buffer"; dNTP (Amersham); Thermo Sequenase TM DNA polymerase; dan $\mathrm{ddH}_{2} \mathrm{O}$ dan dilakukan proses PCR sebagai berikut : denaturasi awal pada $95^{\circ} \mathrm{C}$ selama 5 menit, denaturasi pada $95^{\circ} \mathrm{C}$ selama 30 detik, “annealing" pada $50^{\circ} \mathrm{C}$ selama 30 detik dan polimerisasi pada $70^{\circ} \mathrm{C}$ selama 60 detik.

\section{HASIL DAN PEMBAHASAN}

\section{A. Struktur Dimer}

Hasil elektroforosis ekstraksi DNA dari fraksi mitokondria Paramecium caudatum ditunjukkan pada Gambar 1. Pada gambar, selain DNA mitokondria dalam mitokondria P. Caudatum, terdapat satu kumpulan DNA plasmid. DNA plasmid ini disebut sebagai tipe II (selanjutnya disebut plasmid pGT704-8,2 yang berukuran 8,2 kb; pGT704-4,1 yang berukuran $4,1 \mathrm{~kb}$; plasmid pGT704-2,8 yang berukuran 2,8 kb; dan plasmid pGT704-1,4 yang berukuran 1,4 kb). Hasil ini sama dengan yang ditemukan oleh Endoh et al. (1994) pada stok Hrp2 dan 703s18. Diduga, bahwa DNA 8,2 kb dan 2,8 $\mathrm{kb}$ adalah masing-masing dimer dari monomer $4,1 \mathrm{~kb}$ dan 1,4 kb. Dimer-dimer ini mudah terdisosiasi menjadi monomer apabila diinkubasi pada kondisi panas dengan konsentrasi ion yang rendah. Dalam hal ini, DNA dilarutkan dalam TE (10 mM Tris $-\mathrm{HCl} \mathrm{pH} 7.5)$ dan $1 \mathrm{mM}$ EDTA dan diinkubasi selama 5 menit pada $65^{\circ} \mathrm{C}$. Hasil ini menandakan bahwa pada masing-masing monomer terdapat suatu "sticky end" yang memiliki urutan nukleotida yang saling komplementer sehingga dapat berikatan pada masing-masing ujung komplemennya dan membentuk dimer (Gambar 2). Konsentrasi DNA perlakuan pada lajur 2 dan 3 adalah sama, yang berbeda adalah jumlah yang di masukkan ke dalam masing-masing lajur di mana jumlah yang dimasukkan pada lajur 3 lebih sedikit dibandingkan dengan pada lajur 2 sehingga tampak bahwa pita pada lajur 3 tidak mencerminkan akumulasi dimer yang berdisosiasi menjadi monomer.

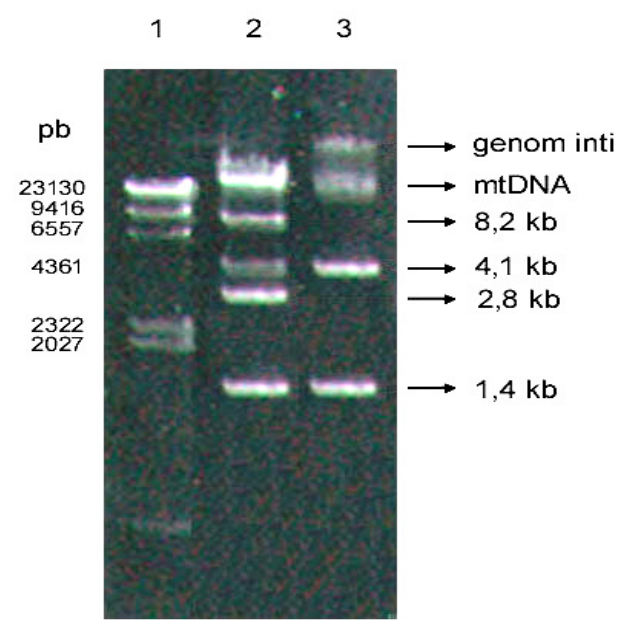

Gambar 1. DNA Paramecium caudatum dari fraksi mitokondria 1 : DNA penanda ( $\lambda$ HindIII); 2 : DNA total sebelum pemanasan, yang terdiri dari DNA mitokondria, pGT704-8,2 yang berukuran $8,2 \mathrm{~kb}$; pGT704-4,1 yang berukuran 4,1 kb; pGT704-2,8 yang berukuran 2,8 $\mathrm{kb}$; dan pGT704-1,4 yang berukuran 1,4 kb; 3 : DNA total setelah pemanasan pada $65^{\circ} \mathrm{C}$, yang terdiri dari DNA mitokondria, $4,1 \mathrm{~kb}$ (pGT704-4,1) dan 1,4 kb (pGT704-1,4).

Dalam penelitian ini ditemukan bahwa dimer $2,8 \mathrm{~kb}$ dan $8,2 \mathrm{~kb}$ menjadi stabil setelah diligasi. Ini menandakan bahwa pembentukan dimer terjadi dengan meninggalkan "nick" dan bukan "gap" antar monomer. "Nick" dapat diligasi sedangkan "gap" tidak dapat diligasi.

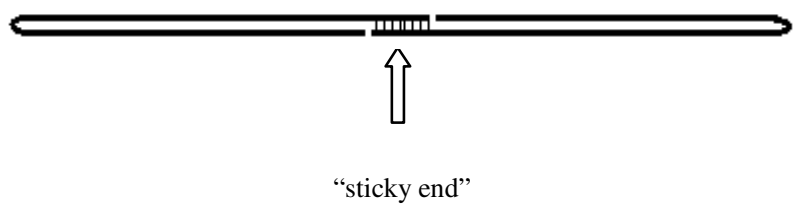

Gambar 2 Struktur Dimer Plasmid pada Mitokondria P. caudatum (Endoh et al., 1994)

\section{B. Analisis Penentuan Urutan Nukleotida}

Untuk mengidentifikasi fungsi-fungsi dari protein yang dikode oleh ORF pada masing-masing klon, urutan asam amino dari protein putatif dibandingkan dengan sekuens pada GenBank [8].

Urutan nukleotida dari masing-masing klon telah ditranslasi dengan menggunakan kode genetik mitokondria 
Protozoa, dengan kodon 'start' ATG dan kodon 'stop' TGA, sedangkan TAA dan TAG mengkode glutamin. Secara keseluruhan berdasarkan hasil penentuan urutan nukleotida, DNA plasmid ini memiliki komposisi basa sebagai berikut : $\mathrm{A}=1120 ; \mathrm{C}=628 ; \mathrm{G}=638$; dan $\mathrm{T}=1264$ sehingga $\mathrm{AT}=65,4 \%$, mendekati mtDNA protista (dengan homologi > 70\%) (Gray et al., 1998).

\section{Urutan Nukleotida pada Dimer 2,8 kb (pGT704-2,8)}

Dimer $2,8 \mathrm{~kb}$ ini mengkode "DNA-directed RNA polymerase" putatif dengan homologi $74 \%$ terhadap sekuens pada plasmid-plasmid mitokondria Pleurotus ostreatus, Hebeloma circinans (75\%), kal dari Gelasinospora sp. (54\%), Neurospora intermedia (54\%), Podospora anserina (55\%), Flammulina velutipes (70\%), pAL2-1 dari Podospora anserina (53\%), Agaricus bitorquis (59\%), T7-like RNA polymerase dari Pylaiella littoralis (50\%) serta (50\%) dengan sekuens pada plastid Plasmodium falciparum.

\section{Urutan Nukleotida pada Dimer 8,2 kb (pGT704-8,2)}

Pada dimer ini, ORF-1 mengkode DNA polimerase alpha putatif dengan homologi $52 \%$ terhadap protein serupa pada Plasmodium falciparum; memiliki homologi (65\%) dengan sitokrom-c oksidase homolog 043L pada "Chilo iridescent virus". Polipeptida yang dikode oleh ORF-2 homolog dengan sitokrom $c$ oksidase rantai II dari mitokondria Paramecium aurelia sebesar 95\%, $P$. tetraurelia (93\%), P. primaurelia (93\%), dan Tetrahymena pyriformis $(72 \%)$.

\section{E. RNA dan DNA polimerase}

"DNA-directed RNA polymerase" (RNAP) merupakan enzim yang diperlukan dalam proses transkripsi. RNAP pada bakteriofag T7 $(100 \mathrm{kD})$ tidak memerlukan faktor lain untuk pengenalan promoter dan merupakan polipeptida tunggal. Menurut referensi [3], karakteristik dari plasmid linier antara lain adalah adanya ORF yang mengkode satu "virus-type" DNA polimerase dan satu RNA polimerase yang mirip dengan RNA polimerase bakteriofag dan mitokondria ragi.

Pada penelitian ini ditemukan RNAP putatif dan "T7 like RNA polymerase" pada dimer $2,8 \mathrm{~kb}$ dan DNA polimerase alpha putatif pada dimer $8.2 \mathrm{~kb}$. Menurut referensi [2] telah ditemukan residu 417-828 dari sekuens plasmid linier maranhar homolog dengan polipeptida dari RNA polimerase mitokondria ragi, bakteriofaga T3 dan plasmid S-2 dari jagung, pClK1, kalilo, dan pEM dari Agaricus bitorquis. Pada penelitian ini ditemukan bahwa RNA polimerase putatif yang dikode oleh plasmid pada mitokondria P. caudatum stok GT704 homolog dengan bakteriofaga $\mathrm{T} 7$ (termasuk dalam bakteriofaga T ganjil) dan Agaricus bitorquis. Dalam kelompok RNA polimerase ini, sejumlah motif yang terkonservasi telah diidentifikasi [4].

Pada RNA polimerase T7 yang telah dikarakterisasi dengan baik, motif-motif tersebut ditemukan dalam suatu fragmen proteolitik yang tidak mempunyai asam amino 172 N-terminal akan tetapi masih mempunyai aktivitas katalitik. Dengan demikian, menurut referensi [4] kehadiran dari motif-motif ini, yaitu motif I sampai dengan
XII, menandakan bahwa RNA polimerase tersebut fungsional.

Pada plasmid maranhar hanya ditemukan 10 motif, yaitu motif III sampai dengan XII. Pada plasmid GT7042,8 pada penelitian ini ditemukan 2 motif seperti tertera pada Gambar 3. Program yang digunakan untuk pencarian motif adalah Multalin Versi 5.4.1 [8], dengan simbol konsensus sebagai berikut: ! adalah I atau V (I = Isoleusin, $\mathrm{V}=$ Valin), $\$$ adalah $\mathrm{L}$ atau $\mathrm{M}(\mathrm{L}=$ Leusin, $\mathrm{M}$ $=$ Metionin $), \%$ adalah $\mathrm{F}$ atau $\mathrm{Y}(\mathrm{F}=$ Fenilalanin, $\mathrm{Y}=$ Tirosin) dan \# adalah N,D,Q, atau E (N= Asparagin, D = Asam aspartat, $\mathrm{Q}=$ Glutamin, $\mathrm{E}=$ Asam glutamat). Meskipun maranhar dan kalilo ditemukan pada spesies dalam genus Neurospora, urutan asam-asam amino dalam RNA polimerasenya tidak berhubungan erat. Urutan asam-asam amino RNA polimerase maranhar lebih mendekati RNA polimerase T3, bahkan dalam kesepuluh motif-motif terkonservasi yang ditemukan sejauh ini, namun urutan asam-asam amino pada RNA polimerase maranhar dan kalilo tidak mirip sama [2].

Motif-motif yang ditemukan pada plasmid pGT7042,8 sesuai dengan motif-motif yang kemukakan oleh referensi [2], dengan simbol konsensus sebagai berikut: $b$ = asam amino bercabang ( $\mathrm{I}=$ Isoleusin, $\mathrm{L}=$ Leusin, dan $\mathrm{V}=$ Valin), $\mathrm{p}=$ asam amino bermuatan positif $(\mathrm{K}=\mathrm{Lisin}$, $\mathrm{R}=$ Arginin, dan $\mathrm{H}=$ Histidin), $\mathrm{n}=$ asam amino bermuatan negatif, $(E=$ asam glutamat, $\mathrm{S}=$ Serin, $\mathrm{D}=$ asam aspartat, $\mathrm{N}=$ asparagin), $\mathrm{f}=$ asam amino $\operatorname{aromatik}(\mathrm{F} Y)$, dan $\mathrm{g}=$ $\mathrm{G}$ (glisin) atau A (asparagin atau asam aspartat).

Motif yang terkonservasi menurut para peneliti tersebut untuk motif $\mathrm{X}$ adalah PN-bHS-Dg, sesuai dengan motif yang ditemukan dalam penelitian ini, yaitu pn!hSL\#A (Gambar 3).

\begin{tabular}{|lccc|}
\hline & V & \\
& & L & A \\
(motif Oeser dan Tudzynski) PN-bHS-Dg & I & G \\
(motif penelitian ini) & Pn & ! hSL\#A \\
& I & N \\
& V & D \\
& & \\
& & Q \\
& & E \\
\hline
\end{tabular}

Gambar 3. Perbandingan motif $\mathrm{X}$ dari penelitian ini dengan motif yang dikemukakan oleh Oeser dan Tudzynski [2]

Perbedaan motif tersebut diduga terkait dengan perbedaan plasmid-plasmid mitokondria acuan, yang digunakan oleh Oeser dan Tudzynski [2], yaitu kalilo, maranhar, pClK1, S-2, dan pEM, dan yang digunakan dalam penelitian, yaitu RNA polimerase pada plasmid-plasmid mitokondria dari Pleurotus ostreatus, Flammulina velutipes, Podospora anserina dan Hebeloma circinans. Alasan pemilihan organisme-organisme tersebut dalam penelitian adalah "DNA-directed RNA polymerase" yang dikode oleh pGT704-2,8 mempunyai homologi yang tinggi dengan protein dari organisme-organisme yang dipilih.

Untuk motif XI, motif yang dikemukakan oleh Oeser dan Tudzynski [2] adalah bHDCF, dan motif ini sesuai 
dengan motif yang ditemukan dalam penelitian ini yaitu IHDCF (Gambar 4).

Dugaan adanya DNA polymerase alpha putatif ditemukan pada pGT704-8,2. DNA polymerase alpha, delta dan epsilon yang termasuk dalam kelas DNA polimerase tipe B, seperti halnya DNA polimerase II pada E. coli, polimerase pada virus-virus eukariota, dan pada bakteriofaga T4 [9]. Pada penelitian ini, DNA polimerase yang ditemukan tidak mempunyai motif-motif yang sesuai dengan DNA polimerase tipe B sehingga tidak dapat disimpulkan bahwa protein tersebut adalah DNA polimerase

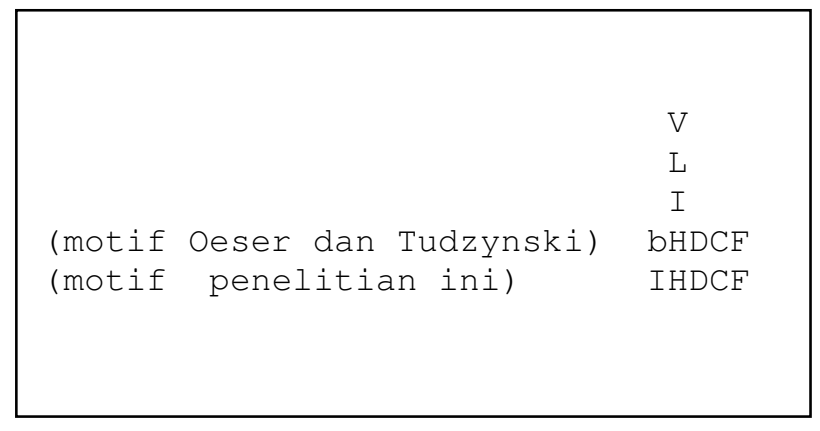

Gambar 4. Perbandingan motif XI dari penelitian ini dengan motif yang dikemukakan oleh Oeser dan Tudzynski.

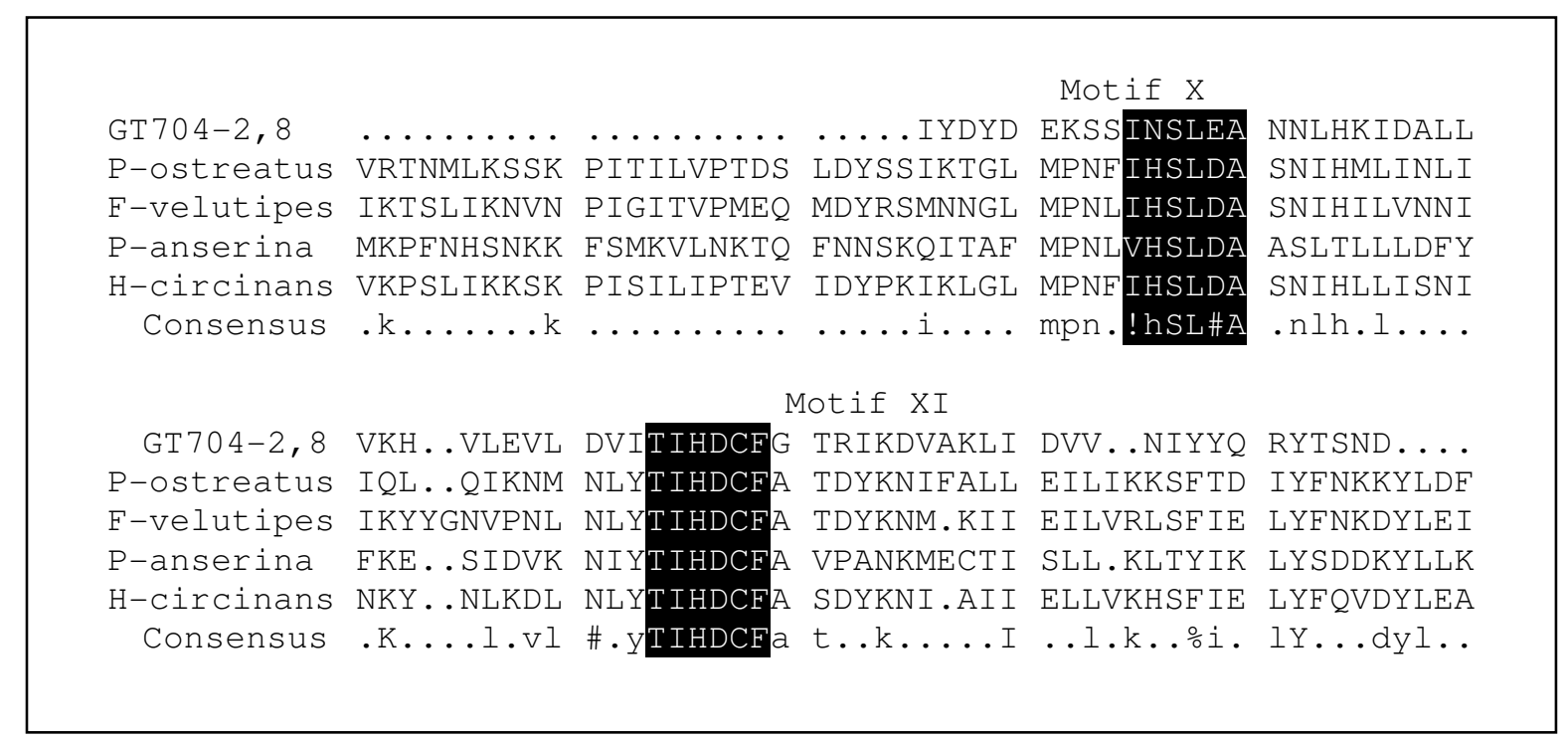

Gambar 5. Perbandingan urutan asam-asam amino dari protein yang dikode dari plasmid pGT704 2,8 kb (pGT704-2,8) dengan RNA Polimerase dari plasmid-plasmid pada Pleurotus ostreatus, Flammulina velutipes, Podospora anserina, dan Hebeloma circinans. Motif X dan XI ditemukan berdasarkan program Multalin ver. 5.4.1. Simbol konsensus yang digunakan adalah: ! adalah I atau V (I= Isoleusin, V= Valin), \$ adalah L atau M $(\mathrm{L}=$ Leusin, $\mathrm{M}=$ Metionin), \% adalah $\mathrm{F}$ atau $\mathrm{Y}(\mathrm{F}=$ Fenilalanin, $\mathrm{Y}=$ Tirosin $)$ dan \# adalah $\mathrm{N}, \mathrm{D}, \mathrm{Q}$, atau $\mathrm{E}(\mathrm{N}=\mathrm{Asparagin}, \mathrm{D}=\mathrm{Asam}$ aspartat, $\mathrm{Q}=$ Glutamin, $\mathrm{E}=$ Asam glutamat) (http://protein.toulouse.inra.fr/multalin.html).

\section{F.Diskusi}

Berdasarkan penelitian yang dilakukan oleh para peneliti di atas maka dapat dikatakan bahwa plasmid pGT704 menyerupai bakteriofaga linier rantai ganda, yang pada situasi normal maka DNA ini tidak ditemukan dalam mitokondria. Akan tetapi apabila sel mencapai fase stasioner, maka DNA tersebut muncul (hasil penelitian yang tidak dipublikasikan). Fenomena ini menyerupai sifat-sifat virus lisogeni yang berusaha untuk menyelamatkan diri dengan cara keluar dari DNA inang pada situasi virus-virus tersebut merasa keberadaan dirinya terancam. Dengan demikian, pada saat sebelum sel-sel $P$. caudatum mencapai fase stasioner maka plasmid terinsersi pada mtDNA inang, dan pada saat menjelang kematian sel, DNA tersebut keluar dari mtDNA dan membawa serta beberapa bagian DNA dari mtDNA.

Berdasarkan hasil yang ditemukan pada plasmid pGT704 di mana beberapa protein putatif yang dihasilkan dari ORF yang diperoleh mempunyai homologi yang sangat tinggi dengan gen-gen yang terdapat pada mtDNA siliata lainnya (Paramecium sp. dan Tetrahymena sp.), diduga bahwa DNA tipe II ini merupakan bagian yang terdelesi dari mtDNA. Hal ini diperkuat dengan ditemukannya motif Evi-1 ACAAGATTA ("Ectopic viral integration site 1 enco- ded factor") pGT704-8,2 [10]. Homologi yang sangat tinggi dengan yang terdapat dalam DNA mitokondria kelompok siliata lainnya adalah gen $\mathrm{NADH}$ subunit 10. Pada mtDNA manusia, daerah yang terdelesi adalah urutan nukleotida yang terdapat didalamnya gen yang mengkode NADH subunit 6 [11]. Evi-1 pertama kali diidentifikasi sebagai suatu sisi integrasi dari "murine leukemia retrovirus" [11].

Berdasarkan urutan nukleotida pada mtDNA manusia yang dikemukakan oleh referensi [11], pada daerah antara posisi nukleotidas 8469 dan 13447 terdapat delesi sepanjang 4977-bp yang umum terjadi yang proporsinya meningkat sesuai dengan bertambahnya umur. Diduga bahwa plasmid pGT704 mengikuti tingkah laku dari mtDNA manusia tersebut. Dikemukakan pula bahwa pada ujung-ujung nukleotida yang terdelesi terdapat "inverted repeat". Plasmid maranhar dan kalilo juga mempunyai "terminal inverted repeat", akan tetapi tingkah laku dari kedua plasmid tersebut bertolak belakang dengan plasmid pGT704 yaitu dapat berintegrasi ke dalam mtDNA sehingga seluruh plasmid tersebut terinsersi ke dalam mtDNA [2], sedangkan plasmid pGT704 pada fase stasioner terdelesi dari mtDNA. Kemungkinan tingkah laku dari pGT704 mi- 
rip dengan plasmid-plasmid $\Delta k a l-1,4$ dan $\Delta k a l-2,8$ yang ditemukan pada mitokondria Neurospora intermedia.

Replikasi dari setiap DNA linier memerlukan suatu mekanisme khusus yang melibatkan ujung 5' dari genom dan sejumlah mekanisme lainnya. Berdasarkan analisis elektron mikroskop, mtDNA dari Paramecium (sekitar 40 kb) mempunyai loop dengan utas tunggal yang tertutup secara kovalen ("covalently-closed single-stranded") pada satu ujung dan suatu struktur terbuka pada ujung lainnya sehingga menyediakan suatu pola replikasi unik. Replikasi dapat berlangsung melalui "hairpin loop" sehingga menghasilkan suatu molekul dimer, yang kemudian diproses menjadi dua monomer yang berikatan silang ("cross-linked"). Mekanisme restorasi dari sekuens terminal pada ujung terbuka masih belum diketahui [12]. Dengan demikian kemungkinan besar bahwa monomer-monomer dari plasmid ini merupakan intermediet dari dimer-dimer pada saat replikasi berlangsung. Diketahui pula bahwa virus linier prokariot seperti T7 dan T4 menghasilkan concatamer dengan cara fusi ujung-ujung genom virus, sehingga awal replikasi (priming) dapat berlangsung menggunakan utas DNA virus tetangganya untuk menyelesaikan replikasi [6]. Sampai saat ini, pembentukan molekul DNA concatamer dianggap terbatas pada faga DNA utas ganda [13], beberapa plasmid bakteri [14] dan beberapa virus hewan [15]. Dalam hal ini, DNA tipe II mungkin mirip dengan genom bakteriofaga. Hipotesis ini didukung oleh pernyataan pada referensi [16] bahwa plasmid-plasmid linier utas ganda dengan protein terikat pada ujung 5' mengingatkan pada struktur genom beberapa virus.

Plasmid barangkali merupakan unit terkecil dari parasit dalam kehidupan ini. Parasit yang sempurna akan bertahan hidup dengan harmonis dengan inangnya, dan ini kelihatannya merupakan strategi dari plasmid kalilo dari Neurospora tetrasperma dan dalam Gelasinospora. Plasmid bahkan mungkin membawa beberapa keuntungan bagi inang. Bentuk virulen juga mewakili strategi harmonisasi parasit atau strategi agresif untuk membunuh dan berpindah ke inang selanjutnya.

\section{KESIMPULAN DAN SARAN}

Berdasarkan hasil yang ditemukan pada penelitian ini dapat disimpulkan bahwa DNA 8,2 kb merupakan dimer dari monomer DNA 4,1 kb dan DNA 2,8 kb merupakan dimer dari monomer DNA 1,4 kb. Masing-masing monomer memiliki ujung lengket utas tunggal yang menghubungkan masing-masing monomer menjadi dimer yang stabil apabila diligasi menggunakan ligase. Berdasarkan analisis urutan nukleotida dimer-dimer tersebut diperoleh bahwa pGT7042,8 memiliki ORF yang mengkode RNA polimerase putatif.

Diduga asal usul DNA plasmid ini adalah elemen yang menyerupai transposon atau virus karena adanya motif EVI-1. DNA plasmid ini terdelesi dari DNA mitokondria karena memiliki beberapa ORF yang homolog dengan yang terdapat pada DNA mitokondria kelompok siliata.
Saran yang dapat diberikan untuk mengidentifikasi produk-produk gen terutama DNA/RNA polimerase yang terlibat dalam proses pemeliharaan diri plasmid dan untuk menentukan urutan nukleotida yang terlibat dalam proses integrasi atau delesi adalah dengan melakukan pengurutan nukleotida pGT704 secara lengkap.

\section{UCAPAN TERIMA KASIH}

Terima kasih kami sampaikan kepada AIEJ (Association of International Education of Japan) yang telah memberikan dukungan finansial sehingga terlaksananya penelitian ini di Laboratorium Genetika Fakultas Sains Universitas Kanazawa Jepang.

\section{DAFTAR PUSTAKA}

[1] Endoh, H., Yazaki, K., Takahashi, M., dan Tsukii, Y., "Hairpin and dimer structures of linear plasmid-like DNAs in mitochondria of Paramecium caudatum." Curr Genet. 27:9094. 1994.

[2] Court, D.A dan Bertrand, H., "A Method for sequensing uncloned termini 07 linear plasmids." Nucleic Acids Res. 19:1714. 1992.

[3] Griffiths, A.J.F., "Natural plasmids of filamentous fungi." Microbiol Rev. 59 :673-685. 1995.

[4] Chan, B.S-H, Court, D.A., Vierula, P.J., Bertrand, H., The kalilo senescence-inducing plasmids of Neurospora is an invertron and encodes DNA and RNA polymerases. Curr Genet . 20: 225-237. 1991.

[5] Hermanns, J. dan Osiewacz, H.D., "The linear mitochondrial plasmid pAL2-1 of a long-lived Podospora anserina mutant is an invertron encoding a DNA and RNA polymerase." Curr. Genet. Dec:22(6):491-500. 1992.

[6] Tsukii, Y., "Evolution of mitochondrial DNA in Paramecium.” Jpn. J. Genet., 69: 307-319. 1994.

[7] Goddard, J.M. dan Cummings, D.J., "Structure and replication of mitochondrial DNA fom Paramecium Aurelia." J. Mol. Biol. Oct 5; 97(4)593-609. 1975.

[8] http://protein.toulouse.inra.fr/multalin.html.

[9] Cavarelli, J., Bomu, W., Liljas, L., Kim, S., Minor, W., Munshi, S., Muchmore, S., Schmidt, T., Johnson,

[10] J., dan Hendry, D.A., "Crystallization and preliminary structure analysis of an insect virus with $\mathrm{T}=4$ quasi-symmetry: Nudaurelia capensis virus." Acta Cryst. B47, 23-29. 1991.

[11] http://www.motif.genome.ad.jp/motifbin/motif_markseq_transfac.

[12] Anderson, S., Baukier, A.T., Barell, B.G., de Bruijn, M.H., Coulson, A.R., Drouin, J., Eperon, I.C., Nierlich, D.P., Roe, B.A., Sanger, F., and Schreier, P.H., "Sequence and organization of the human mitochondrial genome." Nature, Apr 9:290(5806):457-65. 1981.

[13] Nosek, J., Tomáka, E., dan Kucejová., "The chromosome end replication : lessons from mitochondrial genetics. Journal of Appl. Biomedicine. 2 : 71 - 79. 2004.

[14] Kreuzer, K.N., "Recombination-dependent DNA replication in phage T4." Trends Biochem. Sci., 25 : 165 - 173. 2000.

[15] Viret, J.F., Bravo, A. dan Alonso, J.C., "Recombinationdependent concatemeric plasmid replication." Microbiol. Rev. $55: 675-683.1991$.

[16] de Lange, A.M dan McFadden, G., "The role of telomers in poxvirus DNA replication." Curr. Top. Microbiol. Immunol. $163: 71$ - 93. 1990.

[17] Koulintchenko, M., Konstantinov, Y. dan Dietrich, A., "Plant mitochondia actively import DNA via the permebiality transition pore complex." Embo Journal. 22 (6) : 1245 1254. 2003 